\title{
Efficacy of Moringa oleifera Leaf Supplementation for Enhanced Growth Performance, Haematology and Serum Biochemistry of Rabbits
}

\author{
Norah Eid Aljohani, Suha Hashem Abduljawad \\ Department of Nutrition and Food Sciences, Faculty of Family Science, Taibah University, Madinah Munawarah, KSA \\ Email: nouraalrefai@gmail.com
}

How to cite this paper: Aljohani, N.E. and Abduljawad, S.H. (2018) Efficacy of Moringa oleifera Leaf Supplementation for Enhanced Growth Performance, Haematology and Serum Biochemistry of Rabbits. Food and Nutrition Sciences, 9, 1285-1298. https://doi.org/10.4236/fns.2018.911092

Received: October 17, 2018

Accepted: November 19, 2018

Published: November 22, 2018

Copyright $\odot 2018$ by authors and Scientific Research Publishing Inc. This work is licensed under the Creative Commons Attribution International License (CC BY 4.0).

http://creativecommons.org/licenses/by/4.0/

(c) () Open Access

\begin{abstract}
The present work aimed to define the antioxidant effect of addition graded levels (0 mg (T0), $500 \mathrm{mg}$ (T1), $1000 \mathrm{mg}$ (T2) / Kg diet) of dried M. oleifera leaves (DMOL) during the experimental period for 56 days duration on the productive, hematology and some serum biochemical parameters of fifty-one growing rabbits. The results indicated that the DMOL contents of chlorophyll a, b, vitamin c, vitamin E, total flavonoids, total polyphenols, condensed tannins and phytic acid were (1.09 mg/g DW), (0.34 mg/g DW), (0.95 mg/g), $(0.75 \mathrm{mg} / \mathrm{g}),(5.06 \mathrm{mg} / \mathrm{g}),(2.32 \%),(1.72 \%)$ and $(0.98 \%)$, respectively. The result of the final live weight, average daily weight gain (ADWG) and average daily dry matter intake increased significantly with increasing levels of DMOL in diets. Also, the improvement in feed conversion ratio (FCR) was significantly high among the two levels of (DMOL). The serum glucose and urea nitrogen levels significantly decreased as DMOL levels increased. Moreover, there were a significant increase $(P<0.05)$ in Aspartate Aminotransferase (AST), alkaline phosphatase (ALT) and Alkaline phosphatase (ALP) with control group compared with groups 2 and 3. Also, total cholesterol values decreased significantly $(P<0.05)$ by the addition of DMOL in group 3 (19.03\%) and group 2 (10.27\%) compared to control group. White blood cell count, red blood cells and PLT values of control group were significantly lower $(P<0.05)$ than that of groups 2 and 3. Values of Total Volatile Fatty Acids (TVFA) and caecal $\mathrm{pH}$ were significantly $(p>0.05)$ different among treatments. On the contrary, significantly $(P<0.05)$ lowest values of NH3-N were observed in rabbits fed diet $3(23.84 \mathrm{mg} / \mathrm{dl})$, diet $2(26.65 \mathrm{mg} / \mathrm{dl})$ and lastly control diet $(28.51 \mathrm{mg} / \mathrm{dl})$. The total count of bacteria of ceacal content of rabbits in group T2 was significantly $(P<0.05)$ lower than those in control
\end{abstract}


group T0 but similar $(P>0.05)$ to the values of group T1. There was a significant $(P<0.05)$ effect of DMOL supplementation on the percent of carcass, liver and total edible parts of rabbits across treatments, whereas, treatments $\mathrm{T} 2$ and $\mathrm{T} 1$ recorded better results than T0. Under the condition of the present study, the results suggest that DMOL supplementation up to $1000 \mathrm{~g} / \mathrm{Kg}$ diet might improve performance, bacterial community, antioxidant, biochemical parameters and blood constituents of rabbits.

\section{Keywords}

Moringa oleifera, Growth Performance, Biochemical Activity, Carcass, Cacum Activity

\section{Introduction}

Free radicals play a major role in the pathogenesis of many human diseases such as cardiovascular and cancer diseases [1]. Interestingly, natural antioxidants present in food of plant origin such as Moringa oleifera are important tools in obtaining and preserving good health [2].

Moringa oleifera leaves contain a number of important vitamins A, B complex (B1, B3, B6 and B7), C, D, E, K, specific plant pigments with a good profile of amino acids and minerals ( $\mathrm{Ca}, \mathrm{P}$, and $\mathrm{Fe}$ ) [3] [4] [5] and negligible contents of secondary metabolites [6]. In addition, $M$. oleifera families are known to contain rich antioxidant compounds [7], it was also used an antimicrobial agent [8] to promote the immune system against various infections [9].

The biological activities of these plants are due to the presence of phytochemicals (flavonoids and other phenolics) in their leaves [10]. The protection against these radicals by natural antioxidants may be done by enhancing the activities of anti-oxidant enzymes, reducing the intensity of lipid peroxidation and inhibiting generation of free radicals [11].

The aim of the present study was to find out the antioxidant effect of addition graded levels of dried $M$. oleifera leaves (DMOL) on the productive, haematology and plasma biochemical parameters of growing rabbits.

\section{Material and Methods}

The experimental work was carried out at, Animal house of King Khalid hospital, Kingdom of Saudi Arabia (KSA). Packaged Moringa leaf powder (250 g) was purchased from the Moringa plantation unit of the Scientific Association of Moringa, National Research Center, Egypt.

\subsection{Management and Feeding of the Experimental Rabbits}

Fifty-one weaner New Zealand white rabbits were randomly allotted to three experimental treatments with seventeen animals each in a Completely Rando- 
mized Design. Each rabbit received an assigned diet for eight weeks (56 days). The rabbits were given ad libitum drinking clean water and the control diet (T0) while treatments $\mathrm{T} 1$ and $\mathrm{T} 2$ contained $500 \mathrm{mg}$ and $1000 \mathrm{mg}$ of DMOL per one kg of feed for treatments respectively (Table 1). Whereas, the experimental diets T1 and T2 were prepared by adding fine powder of Moringa oleifera leaf leaves to the soft ingredients which included Limestone, Di-Ca-phosphate, DL-Methionine, $\mathrm{NaCl}$, Vit.-Min. premix of the experimental diets and was then well mixed to get perfectly homogenous experimental diets. The experimental diet (Control) contained Soybean meal (44\% CP) (20.9\%), Barley (32\%), Wheat bran (9.2\%), berseem hay (31\%), Molasses (3\%), Limestone (0.7\%), Di-Ca-phosphate (2.2\%), DL-Methionine (0.4\%), $\mathrm{NaCl}(0.3 \%)$, Vit.-Min. premix $(0.3 \%)$. The composition of the control diet and DMOL analyzed nutrient content are shown in Table 1.

\subsection{Growth and Carcass Characteristics}

The all rabbits were kept under similar conditions of management and weighed at the beginning of the trial and every 14 days which used to calculate an average daily weight gain. The average daily feed intake and feed conversion (g feed/g gain) rate were recorded. The amount of feed offered as well as any feed left over were daily weighed and recorded for each animal during the experimental period to calculate average daily feed intake (ADFI). At the end of the experiment (56 day), five rabbits from each treatment were randomly selected, fasted for 18 hours and slaughtered by cutting the jugular vein. Live body weights were recorded prior to slaughter. After evisceration, the evaluation focused on organ weights such as the carcass and giblets (liver, Kidney and heart) and were separately weighed.

\subsection{Analytical Procedure}

Feed samples and the fine powder of Moringa oleifera leaf were taken every week for proximate analyses [12] which are presented in Table 1.

The DMOL content of chlorophylls a and b were determined using spectrometric method described by Dere et al. [13]. Ascorbic acid was assayed by the method described by Khan et al. [14] by using HPLC method. The condensed tannins were determined according to Makkar [15], total phenolic content was determined using Mc. Donald, et al., [16] whereas, flavonoids estimated by method of Kumaran and Karunakaran [17]. The free radical scavenging activity of DMOL on DPPH radical was estimated using the method described by Liyana-Pathiranan et al. [18] at $515 \mathrm{~nm}$. Bioactive compounds, antinutritional components and antioxidant potential of DMOL are presented in Table 2.

\subsection{Blood Sample}

At the end of the feeding trial, blood samples $(4 \mathrm{ml})$ were collected from the ear veins into individually marked vials from each animal on the last day of the 
Table 1. Proximate compositions of the experimental diet and Moringa oleifera leaves.

\begin{tabular}{ccc}
\hline Constituents (\%) & Control group & Moringa oleifera leaves \\
\hline DM & 92.88 & 92.05 \\
OM & 90.88 & 90.25 \\
CP & 17.56 & 22.54 \\
CF & 13.46 & 17.09 \\
EE & 2.3 & 4.65 \\
NFE & 57.56 & 45.97 \\
Ash & 9.12 & 9.75 \\
\hline
\end{tabular}

Table 2. Bioactive compounds, antinutritional components and antioxidant potential of dried Moringa Oleifera leaves.

\begin{tabular}{cc}
\hline \multicolumn{1}{c}{ Items } & Dried M. Oleifera leaves \\
\hline Chlorophyll A (mg/g DW) compounds & 1.09 \\
Chlorophyll B (mg/g DW) & 0.34 \\
Vitamin c (mg/g) & 0.95 \\
Vitamin E (Tocopherol) (mg/g) & 0.75 \\
Total polyphenols (\%) & 2.32 \\
Total flavonoids, (mg/g) & 5.06 \\
\hline Antinutritional component & 1.72 \\
\hline Condensed tannins (\%) & 0.98 \\
\hline Phytic acid (\%) & 78.05 \\
\hline Antioxidant potential & \\
\hline DPPH scavenging activities, \%
\end{tabular}

study. The samples were separated into two lots and used for biochemical and haematological studies.

Firstly, an initial $2.0 \mathrm{ml}$ blood samples were collected into test tubes without anticoagulant were centrifuged at $3000 \mathrm{rpm}$ for 10 minutes in a microcentrifuge to obtain serum which kept at $-20^{\circ} \mathrm{C}$ until analysis which used to determine the biochemical components using a spectrophotometer at a wavelength of $500 \mathrm{~nm}$. Serum contents of cholesterol and liver enzymatic activity (aspartate aminotransferase, (AST), alanine aminotransferase, (ALT) and alkaline phosphatase, (ALP) were measured calorimetrically using commercial kits (purchased from Bio-diagnostic, Cairo, Egypt) according to the manufacturers' instructions. Serum glucose, urea nitrogen and creatinine were determined according to Fawcett and Soctt [19]. Total protein was determined according to Orsonneau et al. [20]. Albumin was determined according to the method of Doumas et al. [21]. Serum globulin concentration was calculated by the difference between total protein 
and albumin. Secondly, for haematological analysis, another $2.0 \mathrm{ml}$ of the blood samples was collected into test tubes with anticoagulant were centrifuged at 3000 $\mathrm{rpm}$ for 10 minutes in a microcentrifuge to obtain serum and kept at $-20^{\circ} \mathrm{C}$ until analysis. Serum contents of blood haemoglobin concentration (HGB), white blood cell count (WBC), thrombocyte count (PLT) using commercial kits were determined by standard procedures described by Davice and Lewis [22].

\subsection{Caecum Activity and Microbial Activity Estimation}

Immediately after the slaughter, the cecum and colon contents were individually removed from five slaughtered rabbits from each group, the cecum was weighted. The fresh cecum $\mathrm{pH}$ was determined instantly after slaughtering using digital pH meter (Orion Research Digital pH meter, model 201) and then the caecal content divided into two samples, one of them was taken to estimate the total anaerobic bacteria count determined by Standard method according to Kim and Goepfert [23] using nutrient agar medium [24], another sample was filtered through four folds of gauze for determination of total volatile fatty acids (VFA) and ammonia nitrogen by steam distillation according to Warner [25]. Total bacterial counts were determined under strict anaerobic conditions according to the method described by Houghtby et al. [26].

\subsection{Statistical Analysis}

Data were statistically analyzed using One-Way Layout with Means Comparisons Procedure SAS [27]. Differences among means were tested by Duncan's Multiple Range Test [28].

\section{Results and Discussion}

The bioactive compounds, antinutritional components and antioxidant potential of DMOL are presented in Table 2. The DMOL contents values were of chlorophyll a $(1.09 \mathrm{mg} / \mathrm{g}$ DW), b $(0.34 \mathrm{mg} / \mathrm{g} \mathrm{DW})$, vitamin c $(0.95 \mathrm{mg} / \mathrm{g})$, vitamin E $(0.75 \mathrm{mg} / \mathrm{g})$, total flavonoids $(5.06 \mathrm{mg} / \mathrm{g})$ and total polyphenols $(2.32 \%)$. Quantitative secondary metabolites estimated in the water leaf extract showed condensed tannins of $1.72 \%$ and phytic acid of $0.98 \%$. The percentage DPPH scavenging activities of Moringa oleifera leaves extract are 78.05, and this increase may be attributed to its hydrogen donating ability of the DMOL.

As presented in Table 3, no statistically significant difference was found for average initial live weight between experimental diets. The result of the final live weight, average, daily weight gain (ADWG) and average daily dry matter intake increased significantly with increasing levels of dried $M$. oleifera leaves in diets and the values of rabbit's weight gains were close to those obtained (21.5 and $22.6 \mathrm{~g} / \mathrm{d}$ ) by Kpodékon et al. [29] and Kpodékon et al. [30]. These findings are in line with the published reports before of rabbits [31] [32] [33] who found that M. oleifera leaves supplementation could play a good impact on growth performance of rabbits with low levels but adverse effects were observed with high levels of $M$. oleifera leaves supplementation. 
Table 3. Effect of dried Moringa oleifera leaves on growth performance and feed conversion ratio of rabbits.

\begin{tabular}{ccccc}
\hline Parameters & T0 & T1 & T2 & \pm SE \\
\hline Number of animals & 17 & 17 & 17 & \\
Av. Initial live weight $(\mathrm{g})$ & $671.81 \mathrm{a}$ & $671.08 \mathrm{a}$ & $669.10 \mathrm{a}$ & 3.10 \\
Final live weight $(\mathrm{g})$ & $2045.93 \mathrm{c}$ & $2179.68 \mathrm{~b}$ & $2333.42 \mathrm{a}$ & 9.63 \\
Total weight gain $(\mathrm{g})$ & $1374.12 \mathrm{c}$ & $1508.6 \mathrm{~b}$ & $1664.32 \mathrm{a}$ & 6.41 \\
Av. Daily weight gain $(\mathrm{g})$ & $24.54 \mathrm{c}$ & $26.94 \mathrm{~b}$ & $29.72 \mathrm{a}$ & 0.08 \\
Av. daily dry matter intake $(\mathrm{g})$ & $70.13 \mathrm{c}$ & $74.91 \mathrm{~b}$ & $80.54 \mathrm{a}$ & 0.16 \\
Feed conversion ratio & $2.86 \mathrm{a}$ & $2.78 \mathrm{~b}$ & $2.71 \mathrm{c}$ & 0.02 \\
\hline
\end{tabular}

a, b and c: Means in the same row having different superscripts differ significantly $(P<0.05)$.

The improvement of productive performance may be due to the increase in feed intake, the fact that $M$. oleifera is rich in amino acids, vitamins especially vitamin A [34] and minerals particularly iron [35], the biological function of $M$. oleifera that have been natural substances which can promote health and alleviate illness. Also, this improvement may be due to M. oleifera was used as antimicrobial agent [36] which might enhance utilization of nutrients. Also, the improvement in feed conversion ratio (FCR) was significantly high among the two levels of dried $M$. oleifera leaves while the best FCR was recorded in diet 3 (5.24\%) and diet $2(2.81 \%)$ compared to control diet that means better returns on investment. This might be due to the presence of bioactive compounds in Moringa oleifera leaves as reported by Lannaon [37] and antibacterial and antioxidant activities of Moringa oleifera leaves [38]. This result is in harmony with those of Alabi et al. [39] who found that addition of $90 \mathrm{~mL}$ and $120 \mathrm{~mL}$ of aqueous Moringa oleifera leaf extracts per liter in broilers diet produced better feed conversion than control diet.

\subsection{Serum Biochemical Parameters}

As shown in Table 4, total protein, albumin and globuline levels determined in this study were significantly reduced $(P<0.05)$ in rabbits of group 3 and group 2 compared to control rabbits and these values are generally influenced by the quality and quantity of protein intake [40]. These observations of albumin and globulin fall within the range of reference values reported for healthy rabbits in previous studies [41] [42] which is an indication of normal systemic protein utilization of the liver [43] for albumin and high immunity in the experimental animals for globulin [44]. These results agree with Asiedu-Gyekye et al., [45] who showed that supplementation of raw powder of DMOL $(40 \mathrm{mg} / \mathrm{kg}) \mathrm{did}$ not show any pathological alteration in rats.

As can be seen from the Table 5, the serum glucose and urea nitrogen levels significantly decreased as DMOL levels increased. No statistically significant difference for serum creatinine was determined in this study between rabbits of $\mathrm{T} 1$ 
Table 4. Effect of dried Moringa oleifera leaves on serum biochemical parameters of growing New Zealand rabbits.

\begin{tabular}{ccccc}
\hline & \multicolumn{3}{c}{ Treatments } & \multirow{2}{*}{ \pm SE } \\
\cline { 2 - 4 } Items & Control & T1 & T2 & \\
\hline Total Protein, (g/dl) & $8.15 \mathrm{a}$ & $7.57 \mathrm{~b}$ & $7.03 \mathrm{c}$ & 0.04 \\
Albumin, (g/dl) & $4.04 \mathrm{a}$ & $3.76 \mathrm{~b}$ & $3.41 \mathrm{c}$ & 0.03 \\
Globuline, (g/dl) & $4.11 \mathrm{a}$ & $3.81 \mathrm{~b}$ & $3.62 \mathrm{c}$ & 0.03 \\
Glucose, (mg/dl) & $95.46 \mathrm{a}$ & $88.29 \mathrm{~b}$ & $85.87 \mathrm{c}$ & 0.15 \\
Urea nitrogen, (mg/dl) & $39.72 \mathrm{a}$ & $35.81 \mathrm{~b}$ & $32.19 \mathrm{c}$ & 0.10 \\
Creatinine, (mg/dl) & $0.68 \mathrm{a}$ & $0.61 \mathrm{~b}$ & $0.57 \mathrm{~b}$ & 0.01 \\
Aspartate aminotransferase, AST (U/L) & 98.11 & 99.54 & 102.03 & 1.49 \\
ALT (U/L) Alanine aminotransferase & 62.83 & 63.09 & 63.91 & 1.08 \\
Alkaline phosphatase, ALP (U/L) & 125.84 & 124.95 & 124.57 & 0.47 \\
Total cholesterol (mg/100ml) & $65.65 \mathrm{a}$ & $58.91 \mathrm{~b}$ & $53.16 \mathrm{c}$ & 0.16 \\
Triglyceride, TG & $0.38 \mathrm{a}$ & $0.31 \mathrm{~b}$ & $0.28 \mathrm{~b}$ & 0.02 \\
\hline
\end{tabular}

Table 5. Effect of dried Moringa oleifera leaf on some haematological parameters of growing New Zealand rabbit.

\begin{tabular}{ccccc}
\hline \multirow{2}{*}{ Items } & \multicolumn{3}{c}{ Treatments } & \multirow{2}{*}{ SE } \\
\cline { 2 - 4 } & T0 & T1 & T2 & \\
\hline white blood cell count, WBC $(\times 109 / \mathrm{L})$ & $7.84 \mathrm{c}$ & $8.91 \mathrm{~b}$ & $10.86 \mathrm{a}$ & 0.13 \\
Red blood cells, RBCs $(\times 1012 / \mathrm{L})$ & $5.21 \mathrm{c}$ & $5.91 \mathrm{~b}$ & $6.48 \mathrm{a}$ & 0.03 \\
PLT $(\times 109 / \mathrm{L})$ & $645 \mathrm{a}$ & $792 \mathrm{~b}$ & $845 \mathrm{c}$ & 3.99 \\
$\begin{array}{c}\text { whole blood haemoglobin concentration, } \\
\text { Hb (g/dl) }\end{array}$ & $11.65 \mathrm{c}$ & $12.36 \mathrm{~b}$ & $12.81^{\mathrm{a}}$ & 0.11 \\
\hline
\end{tabular}

a, b and c: Means in the same row having different superscripts differ significantly $(P<0.05)$.

and T2 but was significantly higher $(P<0.05)$ for control group. Moreover, these results agree with the findings of Jaiswal et al. [9] who indicated that blood glucose level decreased after supplementation of Moringa oleifera aqueous leaf extract to rats that might be due to Moringa oleifera leaf has some effects of increasing the tissue utilization of glucose [46] or by inhibiting gluconeogenesis [47]. The low level of blood urea in the test animals are associated with high protein quality [48] which are indication that the amino acids of $M$. oleifera are balanced [49]. Also, Omobowale et al., [50] reported that the low blood urea observed in Wister rats received $400 \mathrm{mg} / \mathrm{kg}$ body of methanol extract of Moringa Oleifera for 5 weeks.

Moreover, there were a significant increase $(P<0.05)$ in AST, ALT and ALP with control group compared with $\mathrm{T} 1$ and $\mathrm{T} 2$ and these results agree with Sharifudin et al., [51] and Ouedraogo et al. [52] It is likely indicated that Moringa Oleifera leaves have good effect on the health status of the rabbits. The all values 
of kidney activities were within the normal ranges established [53].

Values of triglyceride were higher significantly $(P<0.05)$ for rabbits in control group than those in T1 and T2. Also, results showed that total cholesterol decreased significantly $(P<0.05)$ by the addition of DMOL in group $3(19.03 \%)$ and group $2(10.27 \%)$ compared to control group, as confirmed by Pari and Kumar, [54] who reported that Moringa leaves showed hypocholesterolemic activity. These results of cholesterol values obtained in this study were within the normal physiological range for rabbits $(35.0-66.0 \mathrm{mg} / \mathrm{dl})$ which reported by [55].

Effects of different levels of DMOL on some haematological parameters of growing New Zealand rabbit serum are presented in Table 5. The values of biochemical parameters obtained in this study were in the normal range of values defined for these parameters by previous studies [56] [57] [58] in clinical healthy rabbits. When haematological parameters of control group and group 2 and 3 were compared, white blood cell count, red blood cells and PLT values of control group were significantly lower $(P<0.05)$ than that of T1 and T2. This same trend of result was observed in haemoglobin $(\mathrm{Hb})$ concentration. Similarly, Osman et al. [59] indicated that supplementation of rat's feeds with Moringa oleifera increased significantly platelets count, RBCs count and hemoglobin $(\mathrm{Hb})$ whereas, RBCs and platelets count increased similarly in rabbits at dose of 300 $\mathrm{mg} / \mathrm{kg}$.

This increase in white blood cell count, red blood cells and PLT values and hemoglobin concentration of rabbits may indicate that DMOL is rich in amino acids, vitamins and minerals particularly iron [35] and contain strong antioxidants such as vitamin C [60].

\subsection{Caecum Activity and Microbial Activity}

The caecum activity and microbial activity as affected by feeding different levels of DMOL of rabbits are presented in Table 6. The data from these studies showed that caecal weight and caecal length values of all the treatments were identical to the control $(P>0.05)$. Also, TVFA and caecal $\mathrm{pH}$ were significantly $(p>0.05)$ different among treatments. On the contrary, significantly $(P<0.05)$ lowest values of NH3-N (mg/dl cecal juice) were observed in rabbits fed diet 3 $(23.84 \mathrm{mg} / \mathrm{dl})$, diet $2(26.65 \mathrm{mg} / \mathrm{dl})$ and lastly control diet $(28.51 \mathrm{mg} / \mathrm{dl})$. The data from these studies showed that the phytogenic compounds of DMOL have shown some positive effects such as regulator of the gut flora.

The total count of bacteria of ceacal content of rabbits in group T2 was significantly $(P<0.05)$ lower than those in control group T0 but similar $(P>0.05)$ to the values of group T1. Therefore, the antimicrobial activity of DMOL may be attributed to the presence of these bioactive compounds which may act on microbiota by inhibiting the growth of microbes, interrupting some metabolic processes, interfering with signal transduction modulation, transcriptional and translational disturbances [61]. 
Table 6. Caecum activity and microbial activity of growing New Zealand rabbits as affected by feeding dried Moringa olefira leaves.

\begin{tabular}{ccccc}
\hline \multirow{2}{*}{ Items } & \multicolumn{3}{c}{ Treatments } & \multirow{2}{*}{ \pm SE } \\
\cline { 2 - 4 } & T0 & T1 & T2 & \\
Caecal weight, $g$ & $169.77 \mathrm{a}$ & $169.43 \mathrm{a}$ & $169.73 \mathrm{a}$ & 0.26 \\
Caecal length, cm & $11.98 \mathrm{a}$ & $11.66 \mathrm{a}$ & $11.98 \mathrm{a}$ & 0.18 \\
TVFA (meq./dl cecal juice) & $6.12 \mathrm{a}$ & $6.21 \mathrm{a}$ & $6.25 \mathrm{a}$ & 0.07 \\
NH3-N (mg/dl cecal juice) & $28.51 \mathrm{a}$ & $26.65 \mathrm{~b}$ & $23.84 \mathrm{c}$ & 0.12 \\
Caecal pH & $5.97 \mathrm{a}$ & $5.95 \mathrm{a}$ & $5.92 \mathrm{a}$ & 0.05 \\
Bacterial total count (total count $\times 105)$ & $25.43 \mathrm{a}$ & $23.72 \mathrm{~b}$ & $22.62 \mathrm{~b}$ & 0.35 \\
\hline
\end{tabular}

a, b, c Means in the same row with different superscripts are significantly different $(\mathrm{P}<0.05)$.

Table 7. Carcass characteristics of rabbit groups fed the experimental diets.

\begin{tabular}{|c|c|c|c|c|}
\hline \multirow{2}{*}{ Parameters } & \multicolumn{3}{|c|}{ Treatments } & \multirow{2}{*}{$\pm \mathrm{SE}$} \\
\hline & T0 & $\mathrm{T} 1$ & $\mathrm{~T} 2$ & \\
\hline Pre-slaughter weight (g) & $2045.93 c$ & $2179.68 b$ & $2333.42 \mathrm{a}$ & 9.63 \\
\hline Carcass (\%) & $46.71 c$ & $48.43 b$ & $50.02 \mathrm{a}$ & 0.27 \\
\hline Liver (\%) & $3.14 \mathrm{~b}$ & $3.45 \mathrm{a}$ & $3.51 \mathrm{a}$ & 0.09 \\
\hline Heart (\%) & 0.31 & 0.32 & 0.33 & 0.01 \\
\hline Kidney (\%) & 0.59 & 0.60 & 0.61 & 0.03 \\
\hline Total edible parts (TEP), (\%) & $50.75 c$ & $52.80 \mathrm{~b}$ & $54.47 \mathrm{a}$ & 0.08 \\
\hline
\end{tabular}

a, b and c: Means in the same row having different superscripts differ significantly $(P<0.05)$. Edible giblets $(\%)=\{\text { liver }(\mathrm{g})+\text { kidney }(\mathrm{g})+\text { heart }(\mathrm{g}) / \text { pre-slaughter weight }(\mathrm{g})\}^{*} 100$, Total edible parts $(\%)=\{$ carcass weight $(\mathrm{g})+$ weight of edible giblets $(\mathrm{g}) /$ pre-slaughter weight $(\mathrm{g})\}^{\star} 100$.

\subsection{Carcass Evaluation of Rabbits}

The results of carcass evaluation of rabbits fed experimental diets are presented in Table 7. The present results indicated that there was a significant $(P<0.05)$ effect of dried Moringa olefira leaves supplementation on the carcass (\%), liver (\%) and total edible parts (\%) of rabbits across treatments, whereas, treatments $\mathrm{T} 2$ and $\mathrm{T} 1$ recorded better results than T0. These results may reflect the positively affect the metabolism and immunity of rabbits on the Moringa olefiraleaves diets. This observation agrees with Ologhobo et al., [62] where they reported that higher mean values of slaughter weights were recorded for birds fed diets containing Moringa oleifera leaf. On the other hand, Dougnon et al., [63] reported that Moringa olefira supplementation had no significant effect on the carcass yield.

However, the percent of heart and kidney differences did not show any significance $(P>0.05)$ at the end of the 8 th weeks, however, it was increased marginally with as the inclusion level of Moringa olefira leaves increased.

\section{Conclusion}

Under the condition of the present study, the results suggest that dried Moringa olefira leaves supplementation up to $1000 \mathrm{~g} / \mathrm{Kg}$ diet might improve performance, 
bacterial community, antioxidant, biochemical parameters and blood constituents of rabbits.

\section{Conflicts of Interest}

The authors declare no conflicts of interest regarding the publication of this paper.

\section{References}

[1] Hertog, M.G.L., Hollman, P.C.H. and Katan, M.B. (1992) Content of Potentially Anticarcinogenic Flavonoids of 28 Vegetables and 9 Fruits Commonly Consumed in the Netherlands. Journal of Agricultural and Food Chemistry, 40, 2379-2383. https://doi.org/10.1021/jf00024a011

[2] Scorbrattee, M.A., Neergheen, V.S., Luximon-Ramma, A., Aruoma, O.L. and Bahorun, T. (2005) Phenolics as Potential Antioxidant Therapeutic Agents: Mechanism and Actions. Mutation Research, 579, 200-213.

https://doi.org/10.1016/j.mrfmmm.2005.03.023

[3] Booth, F.E.M. and Wickens, G.E. (1988) Non-Timber Uses of Selected Arid Zone Trees and Shrubs in Africa. FAO Conservation Guide, Rome 92-101.

[4] Fuglie, L.J. (1999) The Miracle Tree: Moringa oleifera: Natural Nutrition for the Tropics. Church World Service, Dakar, 68 p.

[5] Djakalia, B., Guichard, B.L. and Soumalia, D. (2011) Effect of Moringa oleifera on Growth Performance and Health Status of Youn Post-Weaning Rabbits. Research Journal of Poultry Sciences, 4, 7-13.

[6] Kholif, A.E., Gouda, G.A., Morsy, T.A., Salem, A.Z.M., Lopez, S. and Kholif, A.M. (2015) Moringa oleifera Leaf Meal as a Protein Source in Lactating Goat's Diets: Feed Intake, Digestibility, Ruminal Fermentation, Milk Yield and Composition, and Its Fatty Acids Profile. Small Ruminant Research, 129, 129-137. https://doi.org/10.1016/j.smallrumres.2015.05.007

[7] Moyo, B., Oyedemi, S., Masika, P.J. and Muchenje, V. (2012) Polyphenolic Content and Antioxidant Properties of Moringa oleifera Leaf Extracts and Enzymatic Activity of Liver from Goats Supplemented with Moringa oleifera Leaves/Sunflower Seed Cake. Meat Science, 91, 441-447. https://doi.org/10.1016/j.meatsci.2012.02.029

[8] Caceres, A., Cano, O., Samayoa, B. and Aguilar, L. (1990) Plants Used in Guatemala for the Treatment of Gastrointestinal Disorders: Screening of 84 Plants against Enterobacteria. Journal of Ethnopharmacology, 38, 55-73. https://doi.org/10.1016/0378-8741(90)90017-N

[9] Jaiswal, D., Kumar, R.P., Kumar, A., Mehta, S. and Watal, G. (2009) Effect of Moringa oleifera Lam. Leaves Aqueous Extract Therapy on Hyperglycemic Rats. Journal of Ethnopharmacology, 123, 392-396. https://doi.org/10.1016/j.jep.2009.03.036

[10] Atawodi, S.E., Atawodi, J.C., Idakwo, G.A., Pfundstein, B., Haubner, R., Wurtele, G., Bartsch, H. and Owen, R.W. (2010) Evaluation of the Polyphenol Content and Antioxidant Properties of Methanol Extracts of the Leaves, Stem, and Root Barks of Moringa oleifera Lam. Journal of Medicinal Food, 13, 710-716. https://doi.org/10.1089/jmf.2009.0057

[11] Sreelatha, S. and Padma, P.R. (2009) Antioxidant Activity and Total Phenolic Content of Moringa oleifera Leaves in Two Stages of Maturity. Plant Foods for Human Nutrition, 64, 303-311.

[12] AOAC (2006) Association of Official Analytical Chemists. 18th Edition, Official 
Methods of Analysis, Washington DC.

[13] Dere, S., Günes, T. and Sivaci, R. (1998) Spectrophotometric Determination of Chlorophyll-A, B and Total Carotenoid Contents of Some Algae Species Using Different Solvents. Turkish Journal of Botany, 22, 13-17.

[14] Khan, M.M., Rahman, M.M., Murad, A.T.M. and Begum, S.A. (2006) Determination of Vitamin C Content in Various Fruits and Vegetables by UV Spectrophotometric Method at Sylhet Area, Bangladesh. Journal of Environmental Sciences, 11, 190-193.

[15] Makkar, H.P.S. (2003) Effects and Fate of Tannins in Ruminant Animals, Adaptation to Tannins, and Strategies to Overcome Detrimental Effects of Feeding Tannin-Rich Feeds. Small Ruminant Research, 49, 241-256.

https://doi.org/10.1016/S0921-4488(03)00142-1

[16] McDonald, S., Prenzler, P.D., Autolovich, M. and Robards, K. (2001) Phenolic Content and Antioxidant Activity of Olive Extracts. Food Chemistry, 73, 73-84. https://doi.org/10.1016/S0308-8146(00)00288-0

[17] Kumaran, A. and Karunakaran, R.J. (2007) In Vitro Antioxidant Activities of Methanol Extracts of Phyllantus Species from India. Lebens-Wisstechnologie, 40, 344-352. https://doi.org/10.1016/j.lwt.2005.09.011

[18] Liyana-Pathiranan, C.M., Shahidi, F. and Alasalvar, C. (2006) Antioxidant Activity of Cherry Laurel Fruit (Laurocerasus officinalis Roem.) and Its Concentrated Juice. Food Chemistry, 99, 121-128. https://doi.org/10.1016/j.foodchem.2005.06.046

[19] Fawcett, J.K. and Scott, J.E. (1960) Determination of Urea. Journal of Clinical Pathology, 13, 156-159.

[20] Orsonneau, J.L., Douet, P., Massoube, C., Lustenberger, P. and Bernard, S. (1989) An Improved Pyrogallol Red-Molybdate Method for Determining Total Urinary Protein. Clinical Chemistry, 35, 2233-2236.

[21] Doumas, B.T., Watson, W.A. and Biggs, H.G. (1971) Albumin Standards and the Measurement of Serum Albumin with Bromcresol Green. Clinica Chimica Acta, 31, 87-96. https://doi.org/10.1016/0009-8981(71)90365-2

[22] Davice, J.U. and Lewis, S.M. (1991) Practical Haematology. 8th Edition, Longman Ltd., London, 22-28.

[23] Kim, H.U. and Goepfert, J.M. (1971) Occurrence of Bacillus cereus in Selected Dry Food Products. Journal of Milk and Food Technology, 34, 12-15. https://doi.org/10.4315/0022-2747-34.1.12

[24] Difco Laboratories Incorporated (1984) Difco: Manual of Dehydrated Culture Media and Reagents for Microbiological and Clinical Laboratory Procedure. 10th Edition, Michigan.

[25] Warner, A.C.I. (1964) Production of Volatile Fatty Acid in the Rumen. 1: Method of Measurements. Nutrition Abstracts and Reviews, 34, 339-410.

[26] Houghtby, G.A., Maturin, L.J. and Koening, E.K. (1992) Microbiological Count Methods. In: Marshal, R.T., Ed., Standard Methods for the Examination of Dairy Products, American Public Health Association, Washington DC, 16th Edition, 213-246.

[27] SAS (2003) Statistical Analysis System Institute Inc. Users Guide, Version 9, USA.

[28] Duncan, D.B. (1955) Multiple Ranges and Multiple F Test. Biometrics, 11, 1-42. https://doi.org/10.2307/3001478

[29] Kpodékon, T.M., Youssao, A.K.I., Tossou, C.M., Djago, A.Y. and Coudert, P. (2008) Effects of Molasses Incorporation in Rabbit Fattening Diet on Growth Perfor- 
mances. 9th World Rabbit Congress, Verona, 10-13 June 2008, 123-125.

[30] Kpodékon, M., Youssa, A.K.I., Koutinhouin, G.B., Baba, I.L., Dessou, J.M. and Djago, Y. (2009) Effet de la granulation sur les performances de croissance, l'efficacitéalimentaire et la viabilité des lapereauxen condition d'élevage tropical. Revue D’élevage et de Médecine Vétérinaire des pays Tropicaux, 62, 75-80. https://doi.org/10.19182/remvt.10097

[31] El-Badawi, A.Y., Omer, H.A.A., Abedo, A.A. and Yacout, M.H.M. (2014) Response of Growing New Zealand White Rabbits to Rations Supplemented with Different Levels of Moringa oleifera Dry Leaves. Global Veterinaria, 12, 573-582.

[32] Ibrahim, N.H., Morsy, A.S. and Ashgan, M.E. (2014) Effect of Moringa Peregrine Seeds on Productive Performance and Hemato-Biochemical Parameters of Growing Rabbits. Journal of American Science, 10, 7-12.

[33] Abubakar, M.U., Ibrahim, A.U., Yusuf, A.S. and Muhammad, N.A. (2015) Growth Performance, Carcass and Organ Characteristics of Growing Rabbits Fed Graded Levels of Moringa oleifera Leaf Meal in Diets. Bayero Journal of Pure and Applied Sciences, 8, 7-9. https://doi.org/10.4314/bajopas.v8i2.2

[34] Grubben, G.J.H. and Denton, O.A. (2004) Plant Resources of Tropical Africa 2. Vegetables. PROTA Foundation, Wageningen.

[35] Faye, B., Bucheton, B. and Banuls, A.L. (2011) Prevalence of Leishmania Infantum in a Rural Area of Senegal: Analysis of Risk Factors Involved in Transmission to Humans. Transactions of the Royal Society of Tropical Medicine and Hygiene, 105, 333-340. https://doi.org/10.1016/j.trstmh.2011.02.009

[36] Caceres, A., Cabrera, O. and Morales, O. (1991) Pharmacological Properties of Moringa oleifera: Preliminary Screening for Antimicrobial Activity. Journal of Ethnopharmacology, 33, 213-216. https://doi.org/10.1016/0378-8741(91)90078-R

[37] Lannaon, W.J. (2007) Herbal Plants as Source of Antibiotics for Broilers. Agriculture Magazine, 11, 55.

[38] Ghazalah, A.A. and Ali, A.M. (2008) Rosemary Leaves as a Dietary Supplement for Growth in Broiler Chickens. International Journal of Poultry Science, 7, 234-239. https://doi.org/10.3923/ijps.2008.234.239

[39] Alabi, O.J., Malik, A.D., Ng'ambi, J.W., Obaje, P. and Ojo, B.K. (2017) Effect of Aqueous Moringa oleifera (Lam) Leaf Extracts on Growth Performance and Carcass Characteristics of Hubbard Broiler Chicken. Brazilian Journal of Poultry Science, 19, 273-280. https://doi.org/10.1590/1806-9061-2016-0373

[40] RAR (Research Animal Resource) (2009) Reference Values for Laboratory Animals: Normal Haemotological Values. RAR Websites, RAR, University of Minnesota.

[41] Elmas, M., Yazar, E., Uney, K. and Karabacak, A. (2006) Pharmacokinetics of Flunixin after Intravenous Administration in Healthy and Endotoxaemic Rabbits. Veterinary Research Communications, 30, 73-81. https://doi.org/10.1007/s11259-005-3227-7

[42] Melillo, A. (2007) Rabbit Clinical Pathology. Journal of Exotic Pet Medicine, 16, 135-145. https://doi.org/10.1053/j.jepm.2007.06.002

[43] Apata, D.F. (1990) Biochemical, Nutritional and Toxicological Assessment of Some Tropical Legume Seeds. PhD Thesis, Univ. Ibadan, Ibadan.

[44] Burke, J. (1994) Clinical Care and Medicine of Pet Rabbit. Proceedings of the Michigan Vet. Conf., 49-77.

[45] Asiedu-Gyekye, I.J., Frimpong-Manso, S., Awortwe, C., Antwi, D.A. and Nyarko, A.K. (2014) Micro and Macroelemental Composition and Safety Evaluation of the 
Nutraceutical Moringa oleifera Leaves. Journal of Toxicology, 2014, Article ID: 786979.

[46] Luqman, S., Srivastava, S., Kumar, R., Maurya, A.K. and Chanda, D. (2012) Experimental Assessment of Moringa oleifera Leaf and Fruits for Its Antistress, Antioxidant and Scavenging Potential Using in Vitro and in Vivo Assays. Evidence-Based Complementary and Alternative Medicine, 81, 12.

[47] Desta, G., Yalemtsehay, M., Girmai, G., Wondwossen, E. and Kahsay, H. (2011) The Effects of Moringa stenopetala on Blood Parameters and Histopathology of Liver and Kidney in Mice. Ethiopian Journal of Health Development, 25, 52-57.

[48] Eggun, B.O. (1970) Blood Urea-Measurement as a Technique for Assessing Protein Quality. British Journal of Nutrition, 24, 985-988.

[49] Foidl, N. and Paull, R. (2008) Moringa oleifera. In: The Encyclopedia of Fruit and Nuts, CABI, Oxfordshire, 509-512.

[50] Omobowale, T.O., Oyagbemi, A.A., Abiola, J.O., Azeez, I.O., Adedokun, R. and Nottidge, H.O. (2014) Effect of Chronic Administration of Methanol Extract of Moringa oleifera on Some Biochemical Indices in Female Wistar Rats. Nigerian Journal of Physiological Sciences, 29, 107-111.

[51] Sharifudin, S.A., Fakurazi, S., Hidayat, M.T., Hairuszah, I., Moklas, M.A. and Arulselvan, P. (2013) Therapeutic Potential of Moringa oleifera Extracts against Acetaminophen-Induced Hepatotoxicity in Rats. Pharmaceutical Biology, 51, 279-288. https://doi.org/10.3109/13880209.2012.720993

[52] Ouedraogo, M., Lamien-Sanou, A., Ramde, N., Ouédraogo, A.S., Ouédraogo, M., Zongo, S.P., Goumbri, O., Duez, P. and Guissou, P.I. (2013) Protective Effect of Moringa oleifera Leaves against Gentamicin-Induced Nephrotoxicity in Rabbits. Experimental and Toxicologic Pathology, 65, 335-339. https://doi.org/10.1016/j.etp.2011.11.006

[53] Bennett, R.N., Mellon, F.A., Foidl, N., Pratt, J.H., Dupont, M.S., Perkins, L. and Kroon, P.A. (2003) Profiling Glucosinolates and Phenolics in Vegetative and Reproductive Tissues of the Multi-Purpose Trees Moringa oleifera L. (Horseradish Tree) and Moringa stenopetala L. Journal of Agricultural and Food Chemistry, 51, 3546-3553. https://doi.org/10.1021/jf0211480

[54] Pari, L. and Kumar, N.A. (2002) Hepatoprotective Activity of Moringa oleifera on Antitubercular Drug-Induced Liver Damage in Rats. Journal of Medicinal Food, 5 , 171-177. https://doi.org/10.1089/10966200260398206

[55] Slimani, N., Deharveng, G., Unwin, I., Southgate, D.A., Vignat, J., Skeie, G., Salvini, S., Parpinel, M., Møller, A., Ireland, J., et al. (2007) The EPIC Nutrient Database Project (ENDB): A First Attempt to Standardize Nutrient Databases across the 10 European Countries Participating in the EPIC Study. European Journal of Clinical Nutrition, 61, 1037-1056. https://doi.org/10.1038/sj.ejcn.1602679

[56] Jurcik, R., Suvegova, K., Hanusova, E., Massanyi, P., Ryban, L. and Chrenek, P. (2007) Evaluation of Haematological, Biochemical and Histopathological Parameters of Transgenic Rabbits. Journal of Veterinary Medicine Series A, 54, 527-531. https://doi.org/10.1111/j.1439-0442.2007.00976.x

[57] Archetti, I., Tittarelli, C., Cerioli, M., Brivio, R., Grilli, G. and Lavazza, A. (2008) Serum Chemistry and Hematology Values in Commercial Rabbits: Preliminary Data from Industrial Farms in Northern Italy. 9th World Rabbit Congress, Verona, 10-13 June 2008, 1147-1151.

[58] Jenkins, J.R. (2008) Rabbit Diagnostic Testing. Journal of Exotic Pet Medicine, 17, 4-15. https://doi.org/10.1053/j.jepm.2007.12.003 
[59] Osman, H.M., Shayoub, M.E. and Babiker, E.M. (2012) The Effect of Moringa oleifera Leaves on Blood Parameters and Body Weights of Albino Rats and Rabbits. Jordan Journal of Biological Sciences, 5, 147-150.

[60] Morsy, M.R., Jouve, L., Hausman, J.F., Hoffmann, L. and Stewart, J.M. (2007) Alteration of Oxidative and Carbohydrate Metabolism under Abiotic Stress in Two Rice (Oryza sativa L.) Genotypes Contrasting in Chilling Tolerance. Journal of Plant Physiology, 164, 157-167. https://doi.org/10.1016/j.jplph.2005.12.004

[61] Godstime, O.C., Felix, O.E., Augustina, J.O. and Christopher, E.O. (2014) Mechanisms of Antimicrobial Actions of Phytochemicals against Enteric Pathogens-A Review. Journal of Pharmaceutical, Chemical and Biological Sciences, 2, 77-85.

[62] Ologhobo, A.D., Akangbe, E.I., Adejumo, O. and Adeleye, O. (2014) Effect of Moringa oleifera Leaf Meal as Replacement for Oxytetracycline on Carcass Characteristics of the Diets of Broiler Chickens. Annual Research \& Review in Biology, 4, 423-431. https://doi.org/10.9734/ARRB/2014/6017

[63] Dougnon, T.J., Aboh, B.A., Kpodékon, T.M., Honvou, S. and Youssao, I. (2012) Effects of Substitution of Pellet of Moringa oleifera to Commercial Feed on Rabbit's Digestion, Growth Performance and Carcass Trait. Journal of Applied Pharmaceutical Science, 2, 15-19. 